\title{
GOVERNMENT INDEBTEDNESS AND ECONOMIC GROWTH IN THE REPUBLIC OF NORTH MACEDONIA
}

\author{
Martin Noveski \\ Ministry of Finance \\ martin.noveski@finance.gov.mk \\ Nina Mojsova Kjoseva \\ Sparkasse Bank \\ nina.mojsovakjoseva@sparkasse.mk
}

Sasho Kjosev

Faculty of Economics - Skopje, Ss. Cyril and Methodius University

skosev@eccf.ukim.edu.mk

\begin{abstract}
Government consumption plays an important role for stability of the national economy, especially in periods of economic crisis. However, rapidly growing public debt is a concerning issue nowadays, since it might jeopardize economic growth perspectives. Economic theory suggests that public debt has non-linear impact on economic growth in a form of inverted U-shape. In other words, it is believed that after a certain threshold, public debt will have negative impact on economic growth. Given that such threshold varies significantly across countries, the aim of this paper is to calculate the turning point of the public debt impact in the Republic of North Macedonia. For this purpose, we use non-linear multiple regression model for real GDP growth rate as dependent variable, general government public debt-to-GDP ratio (in nominal and squared terms) as key independent variable, as well as several other controlling variables. Since theory also suggests reverse causality between economic growth and public debt, we use three different estimation techniques (Ordinary Least Squares, Two-Stages Least Squares, and Generalized Method of Moments) to deal with potential endogeneity, as well as to cross-validate the results.

Our results show that general government debt in the Republic of North Macedonia positively affects economic growth until it reaches around 30\% of GDP, whereas further indebtedness after that turning point will most likely have negative impact. Given that current debt level is slightly above 40\% (10 percentage points higher than the turning point), whereby due to the COVID-19 crisis it is expected to grow even more in the upcoming years, the need of urgent fiscal consolidation inevitably arises. In this regards, deeper and more comprehensive analysis is needed in order to identify adequate channels for its efficient and effective implementation.
\end{abstract}

Keywords: Public Debt, Economic Growth, Threshold.

JEL classification:C20, E60, H63

http://doi.org/10.47063/EBTSF.2020.0001

http://hdl.handle.net/20.500.12188/9685 


\section{INTRODUCTION}

In 2007, a financial crisis emerged from the U.S. financial system, namely from the banking sector with the bankruptcy of Lehman Brothers. As a result, the fiscal imbalances of several countries grew in such a way that caused a sovereign debt crisis, beginning in Greece and then affecting all Euro-area countries, especially the peripheral countries such as Portugal, Italy, Ireland and Spain (Alfonso and Alves, 2014). The recent global financial crisis triggered a series of orthodox, unconventional monetary and fiscal policies that led to a sharp increase in the sovereign debt of advanced countries. The massive debt build-up reignited the debate about fiscal sustainability and the impact of the accumulation of government liabilities on financial markets and on real economic performance (Calderon and Fuentes, 2013).

Government consumption plays an important role for stability of the national economy, especially in periods of economic crisis. However, rapidly growing public debt is a concerning issue nowadays, since it might jeopardize economic growth perspectives. Economic theory suggests that public debt has non-linear impact on economic growth in a form of inverted U-shape. In other words, it is believed that after a certain threshold, public debt will have negative impact on economic growth.

In the past few decades, North Macedonia records moderate pace of economic growth, whereby several sharp downturns are evident: the first one in 2001, due to the war conflict in that time; the second and the third in 2009 and 2012 respectively, as result of the global economic crisis and its aftershock, the sovereign debt crisis; and the latest in 2017, due to the political instability in the country. In order to deal with all these threats and put the economy on the right track Government needed to react accordingly, often through its fiscal policy. As can be seen from Figure 1, all of those growth threatening events in the past have caused upwards pressure to the general government debtinlong-run, leading to its convergence around $40 \%$ of GDP in the recent years.

Figure 1: Public debt and economic growth in North Macedonia

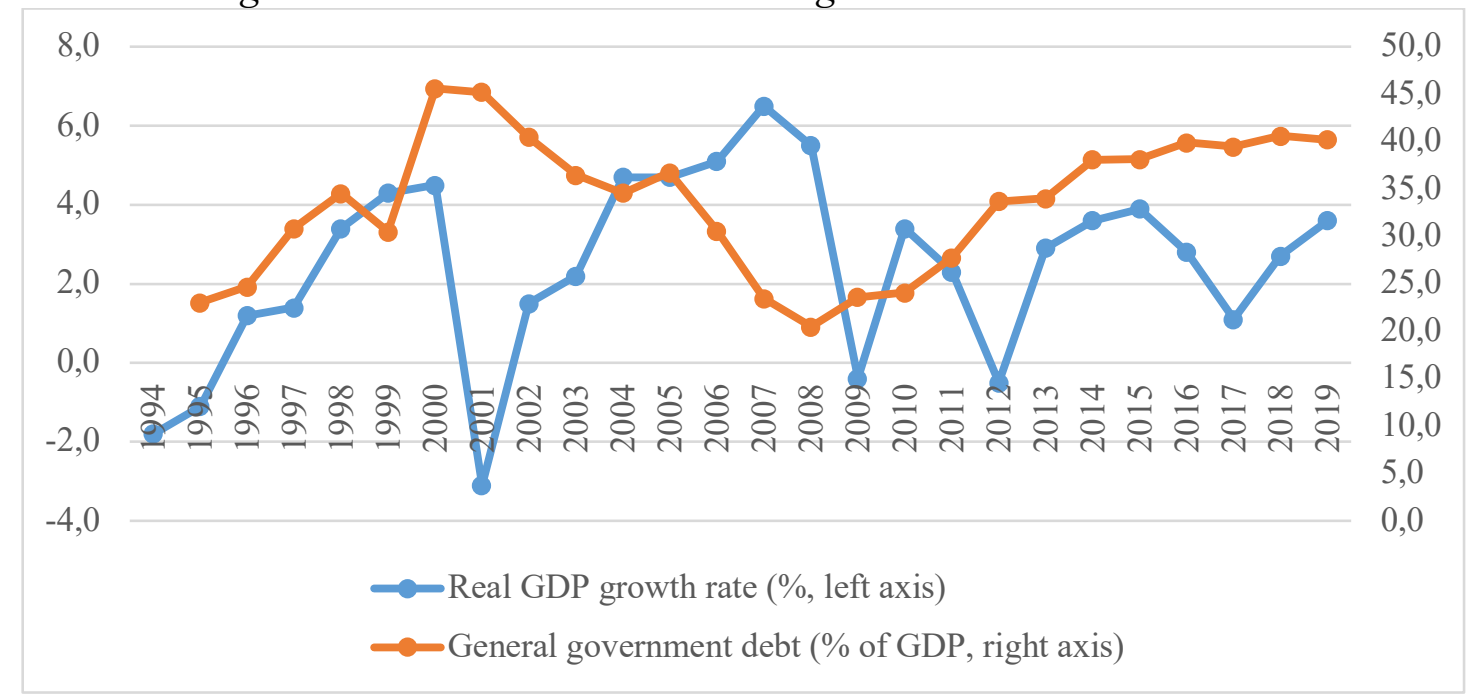

(Source: Authors' illustration)

Unlike the crisis in 2001, which is followed by a debt reduction period, the global economic crisis in 2008 has caused permanent and continuous increase ofgeneral government debt, even in years of economic prosperity. At the same time, real GDP growth rate has barely reached highest $3.9 \%$ in 2009 . Therefore, we ask the question, is there a possibility thatpublic debt might also be a factor that endangers economic growth in North Macedonia?

European regulation recognizes public debt level of $60 \%$ of GDP as acceptable for its member states, which also applies to North Macedonia as candidate country. However, since 
emerging markets cannot sustain as high debt levels as the advanced economies (Reinhart et al., 2003),North Macedonia cannot in fact rely on this threshold(Gavranlieva Andonova and Nikolov, 2019), at least from the viewpoint of its economic growth perspectives.

Under a baseline scenario, IMF (2020) expects general government debt to continue its upward trajectory, reaching $43 \%$ of GDP at the end of 2024. However, macroeconomic and fiscal shocks can significantly increase public debt relative to the baseline. Namely, as a result of the macroeconomic impact of COVID-19 crisis, EC (2020) forecasts increase of general government gross debt by 7 p.p. in 2020, reaching $47.2 \%$ of GDP.

Given the above, this paper investigates the impact of government indebtedness on economic growth in North Macedonia, whereby non-linear (quadratic) relationship is expected. In particular, we aim to estimate the threshold level (turning point) above which general government debt adversely affect economic growth.

\section{LITERATURE REVIEW}

The relationship between public debt expansion and economic growth has attracted interest in recent years, spurred by a sharp increase in government indebtedness in some advanced economies following the global financial crisis. The economic literature examines the impact of public debt on GDP growth and concludes that in the long-run public debt has a negative impact on economic growth. This idea is supported by the results of many empirical studies that have proven the above relationship in advanced and emerging economies.

Economists tend to agree that in the short run, an increase in public debt arising from fiscal expansion stimulates aggregate demand, which should help the economy grow. The longerterm economic impact of public debt accumulation, in contrast, is subject to a more expansive debate. Some argue there is a negative long-term relationship between debt and economic growth, others doubt there is a long-term association between the two for low or moderate levels of public debt. Still others disregard any long-term association.

Substantial attention has been paid to the examination of economic growth-public debt nexus. In theory we can find arguments for positive, negative or neutral effect of government borrowing on economy. From Keynesian point of view, expansionary fiscal policy leads to higher debt level and simultaneously stimulates GDP growth, especially through the mechanism of expenditure multiplier. The neo-classical theory asserts harmful impact of public debt, known as crowding-out effect (Butkus and Seputiene, 2018).

There is currently much cautionary talk in policymaking circles regarding the dangers to the economy's future health posed by crossing a specific threshold in the ratio between government debt and gross domestic product. These fears have been fueled by a recent report "Growth in a time of debt" by researchers Carmen Reinhart and Kenneth Rogoff (2010). They argue that: (1) there is no association between debt and growth at low or moderate levels of debt, but that there exists a well-defined threshold $(90 \%$, in their estimation) of government debt relative to gross domestic product (GDP) above which economic growth is hindered; (2) emerging markets face lower thresholds for external debt (public and private) which is usually denominated in a foreign currency, and (3) there is no apparent contemporaneous link between inflation and public debt levels for the advanced countries as a group.

Most empirical studies confirm the adverse impact of government debt on growth. The growing number of recent works investigates the optimal level of government debt and supports the idea of non-linear, an inverted U-shaped debt-growth relationship. Many authors have analyzed the mutual link between economic growth and public debt and the results, and the methodologies are different in different countries and periods. A growing number of recent works support the idea of debt threshold level (turning point), above which debt starts 
reducing economic growth. The point is that there is no single turning point that could be applied to all countries and a proper investigation is needed on factors, which shape the debt impact on growth (Butkus and Seputiene, 2018).

Alfonso and Alves (2014) analyzed the effect of public debt on economic growth for annual and 5-year average growth rates, as well as the existence of non-linearity effects of debt on growth for 14 European countries from 1970 until 2012. Their results show a negative impact of $-0.01 \%$ for each $1 \%$ increment of public debt, and in addition they found average debt ratio thresholds of around 75\%. Gómez-Puig and Sosvilla-Rivero (2018) analyze the effects of all sources of nonfinancial debt (household, corporate as well as government) accumulation on economic growth in ten euro-area countries during the 1980-2015 period, using of three models (a baseline, an asymmetric and a threshold model) based on the empirical growth literature augmented by debt. Their findings suggest that while public debt thresholds are higher in peripheral than in central countries, private debt thresholds are higher in core euroarea countries.

Checherita and Rother (2010) investigated the average impact of government debt on percapita GDP growth in twelve euro area countries over a period of about 40 years starting in 1970. It finds a non-linear impact of debt on growth with a turning point - beyond which the government debt-to-GDP ratio has a deleterious impact on long-term growth - at about 90$100 \%$ of GDP. At the same time, there is evidence that the annual change of the public debt ratio and the budget deficit-to-GDP ratio are negatively and linearly associated with percapita GDP growth.

Mencingeret al. (2014) examine and evaluate the direct effect of higher indebtedness on economic growth for countries in the EU which are in the epicenter of the current sovereign debt crisis. They employ a panel estimation on a generalized economic growth model augmented with a debt variable, while also considering some methodological issues like the problems of heterogeneity and endogeneity. The calculated debt-to-GDP turning point, where the positive effect of accumulated public debt inverts into a negative effect, is roughly between $80 \%$ and $94 \%$ for the 'old' member states. Yet for the 'new' member states the debtto-GDP turning point is lower, namely between $53 \%$ and $54 \%$. In their other article, Mencingeret al. (2015) confirm the general theoretical assumption that at low levels of public debt the impact on growth is positive, whereas beyond a certain debt turning point a negative effect on growth prevails. They calculated that the debt-to-GDP turning point is roughly between $90 \%$ and $94 \%$ for developed economies. Yet, for emerging countries, the debt-toGDP turning point is lower, namely between $44 \%$ and $45 \%$.

Bilan and Ihnatov (2015) analyzed the relationship between public debt and economic growth for a panel of 33 European countries (28 European Union Member States and 5 candidate countries to European accession) over the period 1990-2011. The results confirm the existence of a „U inverted" relationship, with a maximum debt threshold of about $94 \%$ of GDP. After this threshold public debt is expected to negatively affect the economic growth rate, due to higher interest rates, fear of public debt unsustainability and severe budgetary consolidation measures. However, this threshold is found to be more than twice lower in developing European countries compared to the developed ones, as the former enjoy lower credibility, higher vulnerability to shocks and depend more on external capital transfers.

On the other hand, Gashi (2020) examines the impact of public debt in six countries from South-Eastern Europe over the period 2008 to 2017, by applying three different panel methods: the fixed effects model, the GMM method and the system-GMM method. The results confirm the existence of a „U inverted” relationship, with a maximum debt threshold of about $58 \%$ of GDP. After this threshold, public debt is expected to negatively affect the economic growth rate, due to fear of public debt unsustainability, higher interest rates and severe budgetary consolidation measures. 
Most studies on the relationship between public debt and economic growth implicitly assume homogeneous debt effects across their samples. However, starting from a different perspective, Ahlborn and Schweickert (2016) challenge this view and state that there likely is a great deal of cross-country heterogeneity in that relationship. They argue that different degrees of fiscal uncertainty at comparable levels of public debt between three clusters of economic systems (liberal, continental and nordic) constitute a major source of heterogeneity in the debt-growth relationship. Continental countries face more growth reducing public debt effects than especially Liberal countries, while for Nordic countries a non-linear relationship is discovered, with negative debt effects kicking in at public debt values of around $60 \%$ of GDP.

\section{DATA AND METHODOLOGY}

For the purposes of our research we use annual data for the period 1995 - 2018(24 observations in total). We use several data sources to compile and cross-check our data set, in order to ensure consistency of the data. Primarily we use data from the National Bank of the Republic of North Macedonia and the Ministry of Finance, but we also make use of the European Commission's AMECO database, World Bank's World development indicators database, as well as IMF's World Economic Outlook and Historical Public Debt databases. Following commonly employed methodological procedure (Checherita and Rother (2010); Mencingeret al. (2014); Bilan and Ihnatov (2015), etc.), we use multiple regressionmodel expressing economic growth as a function of the public debt (in nominal and squared terms), as well as a vector of controlling variables,in order to account for other factors that might have significant impact. ${ }^{1}$ Mathematically, our model can be expressed by the following equation:

$$
G D P_{g}=\beta_{0}+\beta_{1} D E B T+\beta_{2} D E B T^{2}+\beta_{3} X+u
$$

Where:

- GDPg - Real GDP growth rate (\%)

- DEBT - Central government debt (\% of GDP)

- $\quad \mathrm{X}-$ Vector of controlling variables

- $\quad \mathrm{u}-$ Error term

Based on the literature review, non-linear relationship in a form of inverted U-shape exists if both $\beta_{1}$ and $\beta_{2}$ coefficients are statistically significant, whereby $\beta_{1}>0$ and $\beta_{2}<0$. This means that up to some point public debt will have positive impact on the economic growth, whereas after that point the impact is negative. In this regard, the turning point (TP), as extremum value, is estimated using the following equation proposed by Lind and Mehlum (2007):

$$
T P=-\frac{\hat{\beta}_{1}}{2 \hat{\beta}_{2}}
$$

However, since TP is calculated as a ratio of the estimated parameters, where the denominator $\hat{\beta}_{2}$ can take values close to zero, it is likely that the moments of TP are undefined, as in the case of the Cauchy distribution (Hirschberg and Lye, 2005). In such case, theoretical

\footnotetext{
${ }^{1}$ The full list of variables used in the analysis is provided at the end of the paper as Annex 1.
} 
literature provides several alternative methods for calculation of the confidence intervals for the extremum value. In particular, we employ two most widely used methods, the Delta method and the Fieller method, as suggested in Hirschberg and Lye (2005):

\section{Delta method}

$$
C I=T P \mp t_{\alpha / 2} \sqrt{\frac{\hat{\sigma}_{1}^{2} \hat{\beta}_{2}^{2}-2 \hat{\beta}_{1} \hat{\beta}_{2} \hat{\sigma}_{12}+\hat{\beta}_{1}^{2} \hat{\sigma}_{2}^{2}}{4 \hat{\beta}_{2}^{4}}}
$$

Fieller method

$$
C I=\frac{t_{\alpha / 2}^{2} \hat{\sigma}_{12}-\hat{\beta}_{1} \hat{\beta}_{2} \mp \sqrt{\left(\hat{\beta}_{1} \hat{\beta}_{2}-t_{\alpha / 2}^{2} \hat{\sigma}_{12}\right)^{2}-\hat{\sigma}_{1}^{2} \hat{\sigma}_{2}^{2}\left(\hat{t}_{2}^{2}-t_{\alpha / 2}^{2}\right)\left(\hat{t}_{1}^{2}-t_{\alpha / 2}^{2}\right)}}{2 \hat{\sigma}_{2}^{2}\left(\hat{t}_{2}^{2}-t_{\alpha / 2}^{2}\right)}
$$

Where:

- $\quad t_{\alpha / 2}$ is critical value for $n-k$ degrees of freedom;

- $\quad \hat{\sigma}_{1}^{2}$ and $\hat{\sigma}_{2}^{2}$ are variances of $\hat{\beta}_{1}$ and $\hat{\beta}_{2}$ respectively;

- $\hat{\sigma}_{12}$ is covariance of $\hat{\beta}_{1}$ and $\hat{\beta}_{2}$;

- $\hat{t}_{1}^{2}$ and $\hat{t}_{2}^{2}$ are $\mathrm{t}-$ statistics of $\hat{\beta}_{1}$ and $\hat{\beta}_{2}$ respectively.

As for the reliability of our estimates, in order to prevent spurious results caused by using non-stationary variables in the regression, we perform unit root tests to determine theorder of integration of the variables.Given that all variables are either stationary in levels, or integrated of 1st order(results in Annex 1), we use first differences of the non-stationary variables in the models (except for the public debt).However, since differenced variables might cause serial correlation of the residuals (Gujarati and Porter, 2009, p.418), we also include autoregressive term in the model. ${ }^{2}$

Additionally, we also check the correlation coefficients in order to eliminate highly correlated independent variables and therefore avoid multicollinearity, as well as variables unrelated toeconomic growth. In this regard, unlike many empirical papers, we do not include real GDP per capita as a proxy for economic development of the country in our models, since it is integrated of order 1 , and its first difference is almost perfectly correlated with the dependent variable.

To ensure robustness of the estimated coefficients, we start by estimation of unrestricted model (as specified in equation 1), including all relevant controlling variables. Afterwards, we gradually exclude statistically insignificant controlling variables, one-by-one, while carefully looking at the stability of $\hat{\beta}_{1}$ and $\hat{\beta}_{2}$.Also, in order to capture unexplained factors (shocks) in 1997 and 2012, which become visible after estimation of the unrestricted model, we augment the model with a time specific dummy variable that has value 1 for these particular years and 0 otherwise.

In addition, since the economic theory also suggestspossible reverse causality between economic growth and public $\mathrm{debt}^{3}$, we employ several different estimation techniques to validate the results: Ordinary Least Squares (OLS); Two-Stages Least Squares (TSLS); and

\footnotetext{
2 This is only applicable for the models estimated with OLS method.

${ }^{3}$ The logic is that higher rates of economic growth might lead to increased debt repayment.
} 
Generalized Method of Moments (GMM). As instruments in TSLS and GMM models we use initially specified controlling variables, as well as GDPg and DEBT variableswith one lag.

Furthermore, in order to prevent any consequences of possible heteroskedasticity in the models, we use robust standard errors in our TSLS and GMM estimates. Baum et al. (2002) suggest that if heteroskedasticity is present, GMM is preferable since estimators would have better efficiency than a simple IV estimators. However, GMM can have poor small sample properties. Therefore, to ensure reliability of our findings, we calculate TPs for all three estimated models.

Finally, all estimated models are subjected to diagnostic tests.

\subsection{Limitations}

Regardless of the strict methodology we follow, there are several limiting factors that we need to beware of. First, it's the data quality and consistency. Namely, in spite of the general guidelines on wider scoping of the public debt (Dippelsmanet al., 2012), there are numerous examples of methodological inconsistencies for its calculation across countries, as well as misinterpretationsof the term public debt. Consequently, there are many empirical papers with incomparable findings, due to the different data they rely on, mostly referring to different levels of the government. In order to expand our data sample to maximum extent, we use data on general government $\mathrm{debt}^{4}$, instead of public debt ${ }^{5}$, since it has longer time series available.

Another limiting factor might be the methodological approach foreconometric analysis. For example, some authors use different econometric techniques (primarily based on dummy variables) to estimate the threshold level. However, we believe that this approachis not always suitable, especially for small samples, and/or if there is an indication that the threshold has not yet been reached (or it is too close to the data range).

Also, unlike many studies that address this issue using panel data for a group of countries, we aim to make use of the country-specific conditions for a single country, North Macedonia in particular. We believe that heterogeneity between countries, even from same geographical region, might be a source for significant disparities, imposing need for generalization.

Finally, from time perspective, our analysis only focuses on the short-runimplications of the public debt, leavinglong-run macroeconomic impact for further research.

\section{RESULTS OF THE ECONOMETRIC ANALYSIS}

Following the above methodology, our results show that general government debt in North Macedonia has non-linear impact on economic growth in a form of inverted U-shape. Model parameters $\hat{\beta}_{1}$ and $\hat{\beta}_{2}$,estimated as specified in equation 1 , are both statistically significant and have proper signs $\left(\hat{\beta}_{1}>0\right.$ and $\left.\hat{\beta}_{2}<0\right)$, which is sufficient evidence in favor of this claim. Based on our estimated models, we calculatea turning point of around $30 \%$ of GDP, above which further increase of the general government debt would negatively affect economic growth. Furthermore, we calculate $95 \%$ confidence intervals as stated in equations 3 and 4, which in all cases lie within the data range for the general government public debt (between 20.5 and 45.6).

Table 1 summarizersfinal estimated models for each estimation method used, corresponding TPs and confidence intervals. In addition, confidence intervals for both methods of calculation are illustrated in Figure 1. ${ }^{6}$

\footnotetext{
${ }^{4}$ Covering central government, extra budgetary funds and municipalities.

${ }^{5}$ General government debt plus public enterprises' guaranteed debt and non-guaranteed debt.

${ }^{6}$ Closer look in the models is provided in Annex 2. However, in-between model estimates are not presented.
} 
Table 1: Estimated coefficients (final estimated models)

\begin{tabular}{|c|c|c|c|}
\hline Variable & OLS & TSLS & GMM \\
\hline $\mathrm{C}$ & $-7.52 * * *$ & $-9.87 *$ & $-9.52 *$ \\
\hline DEBT & $0.798214 *$ & $0.998437 *$ & $0.95304 *$ \\
\hline $\operatorname{DEBT}^{\wedge} 2$ & $-0.013256 *$ & $-0.016239 *$ & $-0.015736 *$ \\
\hline $\mathrm{BB}$ & $0.449918 *$ & $0.497797 *$ & $0.291444 * *$ \\
\hline M1 & $0.114319 *$ & $0.094613 *$ & $0.094654 *$ \\
\hline $\mathrm{D}$ (LIFE) & $-7.430684 * *$ & $-10.90331 *$ & $-10.13387 *$ \\
\hline $\mathrm{D}(\mathrm{EXCH})$ & & $0.077922 * *$ & $0.084343 *$ \\
\hline D(NETEX) & & $-0.258473 *$ & $-0.262778 *$ \\
\hline $\mathrm{D}(\mathrm{RIR})$ & & & $-0.143129 * *$ \\
\hline $\operatorname{AR}(1)$ & $-0.68 *$ & & \\
\hline DUM & $-2.6 * *$ & $-3.96 *$ & $-3.94 *$ \\
\hline Turning Point & 30.1 & 30.7 & 30.3 \\
\hline 95\% CI (Fieller method) & $26.9-31.7$ & $29-32.2$ & $28.3-31.8$ \\
\hline 95\% CI (Delta method) & $28.1-32.1$ & $29.3-32.2$ & $28.6-31.9$ \\
\hline
\end{tabular}

(Source: Authors' calculation)

Figure 1: 95\% confidence intervals for the calculated turning point

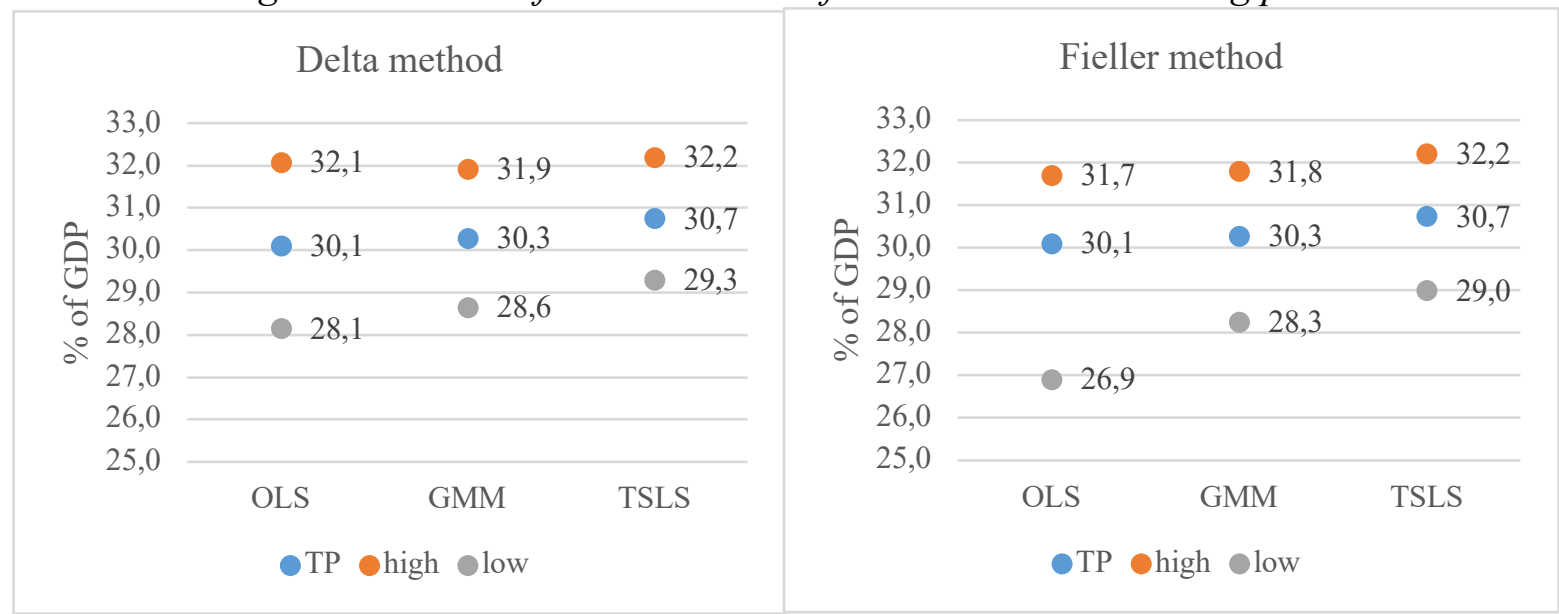

(Source: Authors' calculation)

Our findings are stable and robust to changes in model specification. Based on 14 estimates of the econometric model in total ${ }^{7}$ using different specifications for the controlling variables, calculated TPs vary in relatively narrow range (between 29.4 and 30.8). The average TP in this regard is 30 and its standard deviation is 0.45 , which gives coefficient of variation equal to 1.5 .

Conducted diagnostic tests show that all of theassumptions regarding the reliability of the models are met, although there might be some possible misspecifications in the TSLS final 
model. ${ }^{8}$ In other words, all estimated models are statistically significant and well-fitted, with adjusted R-squared coefficients of around 0.8, meaning that models explain $80 \%$ of the variations in the dependent variable. Residuals are normally distributed, homoskedastic and no serially correlated. Regarding TSLS and GMM models, J-statistics is low ( $p>\alpha$ ), which confirms the joint validity of the over-identifying restrictions, meaning that instruments are consistent (Roodman, 2009). However, the endogeneity tests fail to reject the null hypothesis that DEBT and $\mathrm{DEBT}^{\wedge} 2$ variables areexogenous (low difference in $\mathrm{J}$ statistics), thus suggesting that maybe OLS estimation would be better choice. In any case, the results we obtain from all estimated models are unanimous, although OLS model suggests slightly wider confidence intervals for the turning point (Figure 1).

\section{CONCLUSION}

The question, whether public debt is a means of or a burden on economic growth, is widely discussed in the scientific literature. The theory provides arguments how government borrowing and increasing debt can stimulate, impede or make no influence on economic development. There is quite a lot of empirical research devoted to the analysis of the impact the public debt makes on economic growth, despite this, the results are ambiguous. The growing number of recent research in this field confirms non-linear inverted U-shaped public debt-growth nexus, however estimated public debt threshold level (or turning point) above which relationship turns from positive to negative, varies sharply across studies (Butkus and Seputiene, 2018).

Following this idea, our objective was to examine if such relationship exists in the case of North Macedonia, and if yes, to calculate the corresponding turning point. For this purpose, we use multiple regression model for the period 1995 - 2018, having GDP growth rate as dependent variable, and general government debt-to-GDP ratio (in nominal terms and squared) as independent variables (plus some controlling variables). To ensure robustness of the results, we follow strict predefined methodological procedure, as well as three different model estimation methods.

Our results undoubtedly go in favor of the hypothesis that public debt affects economic growth non-linearly in a form ofinverted U-shape, whereby we calculate the turning point for the case of North Macedoniaat around 30\% of GDP.

Given that current debt level is slightly above 40\% (10 percentage points higher than the turning point), whereby due to the COVID-19 crisis it is expected to grow even more in the upcoming years, the need of urgent fiscal consolidation inevitably arises. In this regard, IMF (2020)explicitly notes that space for fiscal policy as main countercyclical stabilization tool in North Macedonia is limited. Hence, to help unlocking economy's growth potential and reduce vulnerability to shocks, sound macroeconomic management,along with stronger efforts to improve public debt management,arerecommended.

To conclude, even though general government debt level of $30 \%$ of GDP (as calculated) would significantly reduce the debt sustainabilitypressure in North Macedonia, while promoting growth at the same time, it should not be mistaken as optimal level of indebtedness. Namely, as IMF suggests, to ensure resilience to shocks(such as the ongoing COVID-19 crisis) without jeopardizing economic growth perspectives, we need sufficient fiscal buffer to mitigate their impact. Therefore, the optimal debt level for North Macedonia would be somewhere below this point, depending on the fiscal capacity of the country.

\footnotetext{
${ }^{8}$ RESET test with one fitted term included rejects the null hypothesis that the model is well-specified. On the other hand, RESET test with two fitted terms included fail to reject the null hypothesis.
} 


\section{REFERENCES}

Ahlborn, M. and Schweickert, R. (2016), "Public debt and economic growth: Economic systems matter", cege Discussion Papers, No. 281, University of Göttingen, Center for European, Governance and Economic Development Research (cege), Göttingen. Available at: http://hdl.handle.net/10419/129092 [Accessed: 01.06.2020].

Alfonso, A. and Alves, J. (2014), "The Role of Government Debt in Economic Growth", WP16/2014/DE/UECE, Department of Economics, Lisboa School of Economics and Management.

Baum, C.F., Schaffer, M.E. and Stillman, S. (2002), "Instrumental variables and GMM: Estimation and testing", Boston College Economics Working Paper 545, 02 November

Bilan, I. and Ihnatov, I. (2015), "Public Debt and Economic Growth: A Two-Sided Story", International Journal of Economic Sciences, Vol. IV, No. 2, pp. 24-39.

Butkus, M. and Seputiene, J. (2018), "Growth Effect of Public Debt: The Role of Government Effectiveness and Trade Balance", Economies, 6(4), 62. Available at:https://doi.org/10.3390/economies6040062[Accessed: 01.06.2020].

Calderon, C. and Fuentes, J.R. (2013), "Government Debt and Economic Growth", IDB Working Paper series IDB-WP-424, Inter-American Development Bank.

Checherita, C. and Rother, P. (2010), "The Impact of High and Growing Government Debt on Economic Growth: An Empirical Investigation for the Euro Area", Working Paper No. 1237, European Central Bank.

Dippelsman, R., Dziobek, C. and Gutiérrez Mangas, C.A. (2012), "What Lies Beneath: The Statistical Definition of Public Sector Debt, an Overview of the Coverage of Public Sector Debt for 61 Countries", IMF Staff Discussion Note, International Monetary Fund, 27 July.

EC (2020), "European Economic Forecast: Spring 2020", European Economy Institutional Paper 125, European Commission. Available at: https://ec.europa.eu/info/publications/economic-and-financial-affairs-publications en

[Accessed: 01.06.2020].

Garvanlieva - Andonova, V. and Nikolov, M. (2019), Political economy of public debt \& debt sustainability: The case of Macedonia, Implementing the IMF's debt sustainability analysis tool for market access countries to Macedonia, Center for economic analyses - CEA, Skopje.

Gashi, B. (2020), "The Impact of Public Debt on the Economic Growth in South Eastern Europe: An Empirical Panel Investigation”, Economic Studies (Ikonomicheski Izsledvania), Vol. 29, No. 2, pp. 3-18.

Gómez-Puig, M. and Sosvilla-Rivero, S. (2018), "Nonfinancial debt and economic growth in euro-area countries", Journal of International Financial Markets, Institutions \& Money, Vol. 56, pp. 17-37.

Gujarati, D.N. and Porter, D.C. (2009), Basic Econometrics, 9th edition, McGraw-Hill/Irwin. Hirschberg, J.G. and Lye, J.N. (2005), "Inferences for the extremum of quadratic regression models", The University of Melbourne, Department of Economics, Research paper Number 906.

IMF (2020), "Executive Board Concludes 2019 Article IV Consultation with the Republic of North Macedonia", IMF Country Report No. 20/24, 27 January.

Lind, J.T. and Mehlum, H. (2007), "With or Without U? - The appropriate test for a U shaped relationship", Oxford Bulletin of Economics and Statistics, Vol. 72, No. 1, pp. 109-118.

Mencinger, J., Aristovnik, A. and Verbič, M. (2014), “The Impact of Growing Public Debt on Economic Growth in the European Union", Amfiteatru Economic, Vol. 16, No. 35, pp. 403-414. Available at: http://www.amfiteatrueconomic.ro/RevistaDetalii_EN.aspx?Cod=51 [Accessed: 01.06.2020]. 
Mencinger, J., Aristovnik, A. and Verbič, M. (2015), "Revisiting the Role of Public Debt in Economic Growth: the Case of OECD Countries", Engineering Economics, Vol. 26, No. 1, pp. 61-66.

Reinhart, C. and Rogoff, K. (2010), "Growth in a Time of Debt”, NBER Working Paper No. 15639.

Reinhart, C., Rogoff, K. and Savastano, M. (2003), "Debt Intolerance”, Brookings Papers on Economic Activity, Vol. 1, pp. 1-74.

Roodman, D. (2009), "How to do xtabond2: An introduction to difference and system GMM in Stata", The Stata Journal, Vol. 9, No. 1, pp. 86-136.

\begin{tabular}{|c|c|c|c|c|}
\hline Variable & Indicator & Source & Factor & Integration \\
\hline GDP g & Real GDP growth rate $(\%)$ & NBRNM & Economic growth & $\mathrm{I}(0)$ \\
\hline Debt & General government debt ( $\%$ of GDP) & MoF/AMECO & Indebtedness & $\mathrm{I}(1)$ \\
\hline $\mathrm{BB}$ & Budget balance $(\%)$ & NBRNM/Mof & Fiscal-budgetary policy & $\mathrm{I}(0)$ \\
\hline UN & Unemployment rate $(\%)$ & NBRNM & \multirow{4}{*}{$\begin{array}{l}\text { Labor and human } \\
\text { capital }\end{array}$} & $\mathrm{I}(1)$ \\
\hline POP g & Population growth (\%) & WDI & & $\mathrm{I}(1)$ \\
\hline LIFE & Life expectancy at birth & WDI & & $\mathrm{I}(1)$ \\
\hline SCHOOL & School enrollment, secondary $(\%$ & WDI & & $\mathrm{I}(1)$ \\
\hline GFCF $\mathrm{g}$ & Gross fixed capital formation growth & WDI & Capital acumulation & $\mathrm{I}(0)$ \\
\hline INF & Inflation rate (period average) & NBRNM & \multirow{3}{*}{ Monetary policy mix } & $\mathrm{I}(0)$ \\
\hline RIR & Real interest rates $(\%)$ & WDI & & $\mathrm{I}(1)$ \\
\hline M1 & Monetary base M1, annual change (\%) & NBRNM & & $\mathrm{I}(0)$ \\
\hline TRADE & Trade $(\%$ of GDP) & WDI & \multirow{3}{*}{$\begin{array}{l}\text { Openness of the } \\
\text { economy and external } \\
\text { competitiveness }\end{array}$} & $\mathrm{I}(1)$ \\
\hline NETEX & Net exports ( $\%$ of GDP) & WDI & & $\mathrm{I}(1)$ \\
\hline $\mathrm{EXCH}$ & Exchange rate $\mathrm{MKD} / \mathrm{USD}$, average & NBRNM & & $\mathrm{I}(1)$ \\
\hline
\end{tabular}

\begin{tabular}{|c|c|c|c|c|c|c|}
\hline Variable & OLS ur & OLS final & TSLS ur & TSLS final & GMM ur & GMM final \\
\hline $\mathrm{C}$ & $-4 . \overline{61}$ & $-7.5 \overline{2} * * *$ & $-8.3 \overline{1}$ & $-9.87 *$ & $-7.5 \overline{6}$ & $-9.52 *$ \\
\hline DEBT & 0.606 & $0.798 *$ & 0.859 & $0.998 *$ & 0.820 & $0.953 *$ \\
\hline $\mathrm{DEBT}^{\wedge} 2$ & -0.010 & $-0.013 *$ & -0.014 & $-0.016 *$ & -0.014 & $-0.016 *$ \\
\hline BB & $0.437 * *$ & $0.450 *$ & $0.372 * * *$ & $0.498 *$ & $0.362 * *$ & $0.291 * *$ \\
\hline M1 & $0.140 *$ & $0.114 *$ & $0.112 * *$ & $0.095 *$ & $0.10 *$ & $0.095 *$ \\
\hline D(LIFE) & $-10.682 * *$ & $-7.431 * *$ & $-13.526 * *$ & $-10.903 *$ & $-11.727 *$ & $-10.134 *$ \\
\hline $\mathrm{D}(\mathrm{EXCH})$ & -0.041 & & -0.013 & $0.078 * *$ & 0.010 & $0.084 *$ \\
\hline D(NETEX) & 0.008 & & -0.214 & $-0.258 *$ & -0.200 & $-0.263 *$ \\
\hline $\mathrm{D}(\mathrm{RIR})$ & -0.067 & & -0.178 & & $-0.199 * * *$ & $-0.143 * *$ \\
\hline D(TRADE) & -0.029 & & -0.030 & & -0.020 & \\
\hline $\mathrm{AR}(1)$ & $-0.67 * *$ & $-0.68 *$ & & & & \\
\hline DUM & & $-2.61 * *$ & & $-3.96 *$ & & $-3.94 *$ \\
\hline Turning Point & 29.6 & 30.1 & 30.8 & 30.7 & 30.3 & 30.3 \\
\hline R-squared & 0.79 & 0.85 & 0.74 & 0.88 & 0.73 & 0.90 \\
\hline Adjusted R-squared & 0.61 & 0.78 & 0.56 & 0.81 & 0.54 & 0.82 \\
\hline F-statistic & $4.5 *$ & $12.4 *$ & $4.0 * *$ & $11.5 *$ & & \\
\hline RESET test (1) & 0.49 & 0.25 & 0.23 & $3.15 * * *$ & & \\
\hline RESET test (2) & 1.12 & 0.16 & 0.74 & 1.74 & & \\
\hline White test & 8.96 & 6.80 & 10.50 & 6.65 & & \\
\hline S.C. LM test (1) & 0.29 & 0.34 & 0.74 & 1.13 & & \\
\hline S.C. LM test (2) & 3.64 & 0.40 & 2.81 & 1.28 & & \\
\hline Durbin-Watson stat & 1.93 & 1.85 & 2.25 & 2.31 & 2.07 & 2.01 \\
\hline Jarque-Bera stat & 1.78 & 0.86 & 0.23 & 0.29 & 1.50 & 2.25 \\
\hline J-statistic & & & 4.85 & 8.08 & 5.79 & 5.15 \\
\hline $\mathrm{d}(\mathrm{J}$-stat. $)$ & & & 0.54 & 0.29 & 0.44 & 0.32 \\
\hline Instrument rank & & & 15 & 16 & 15 & 16 \\
\hline
\end{tabular}

(Source: Authors' compilation) 